\title{
Research of Chinese Government Financial Reform Based on the Comparisons of Advanced Budget Management Modes
}

\author{
Jingxin Huang1, Hongsheng Xia² \\ Management School, Jinan University, Guangzhou, China \\ Email: 1018558242@qq.com
}

Received 12 November 2014; revised 12 December 2014; accepted 18 December 2014

Copyright (C) 2014 by authors and Scientific Research Publishing Inc.

This work is licensed under the Creative Commons Attribution International License (CC BY). http://creativecommons.org/licenses/by/4.0/

\section{(c) (i) Open Access}

\begin{abstract}
Finance is the basis of national administration and an important pillar; scientific fiscal and taxation systems can optimize the allocation of resources, maintain market unity, promote social fairness, and achieve long-term stability of system security state. In this paper, through studying related official documents of government financial reform, I put forward my own views on the location of fiscal functions; studying the advanced budget management system of China and foreign countries can provide direction and reference suggestions for the reform of local government financial departments. This article provides a good advice and a theoretical basis to the modern financial reform which is about to begin.
\end{abstract}

\section{Keywords}

Government Financial Reform, Finance Management, Advanced Budget Management Mode, Function Positioning, Local Finance Department

\section{Introduction}

20 Years of Tax Distribution System laid the foundation for government financial management system in China. But with the development of the situation, some problems are gradually exposed. Central and local government financial authority and powers do not match very scientific expenditure offside phenomenon; these can be very important constraints of sustainable development of China's economy. "Land finance", real estate bubble, local debt risk accumulation, overcapacity and conflict in other macro areas have become increasingly prominent. In order to avoid the "middle-income trap", and make public gain economic dividends of reform, The Third Ple- 
nary Session was held. This conference is fully focused on deepening reform, but the taxation reform is the most important and difficult part in economic reform. "Finance is the basic and important pillar of national governance" and "to build modern government financial system" was first proposed in this conference.

\section{The Function Positioning of Government Financial}

It redefines the fiscal functions of our public finance after analyzing the Western public finance theories and studying the current economic features of our country (Strengthen the Budget Management and Supervision System Research Group, 2010).

According to The Third Plenary Session, finance is an important pillar of the national foundation and governance; and a scientific fiscal and taxation systems can optimize the allocation of resources and maintain market unity, promote social justice, achieve long-term stability. The Chinese government must improve legislation, make the power clear, reform the tax system, make the tax burden stable, make the budget transparent, improve efficiency of fiscal and make both central and local initiative be brought into play to establish a modern government financial system. Which need to improve the budget management system, improve the tax system, and establish clearly responsibility system governance and expenditure? But in fact government entities at all levels of various departments as a social organization unit is fiscal adjustment object. The interests of the government sector itself, as it was, as well as the ability of government to fulfill public responsibilities and ways are subject to the regulation of government financial, fiscal is the mother of society politics, "the basis and important pillar of national governance". Finance major functions should be organizing local fiscal revenue, making the annual budget, balancing funds, responsible for the implementation of the budget, Evaluation of the efficiency in using fiscal fund (Lee \& Johnson, 2010).

Finance should first serve the socialist democratic politics and socialist market economy, that is to say, finance is the basis of national administration and an important pillar, scientific fiscal and taxation systems can optimize the allocation of resources, maintain market unity, promote social fairness, and achieve long-term stability of system security state. To serve the socialist democratic politics, namely, science government financial system which was putted forward during the 18th CPC central committee is to promote social justice, to realize the system guarantee of the national security, is the foundation of governance. To service the socialist market economy, to optimize the allocation of resources, to safeguard the unity of the market, to make the system of socialist market economy more dynamic, all of the above functions should be the meaning of modern government financial system.

Secondly, finance should serve the government departments and taxpayers as the main objects, taxpayers including enterprise and individuals. Finance should serve for the government, let the government departments perform their functions better, and to serve for public better. Then, how to serve the government? The finance should guarantee the funding support to make the government's policy ideas and goals come true. The government's efficiency is the most important criterion to measure whether the finance service the government qualified. That is to say, finance should let the government department to run more efficiently and quickly to achieve then government's policy ideas. The main customers of government financial should be public (enterprise), policy of the government is also set up for serving the public. As the standard of success for government financial services is whether can bring benefits to the general public (enterprise), such as increasing the income of public, solving problems, bring convenience to public life, etc. (The Financial Secretary, 2003) (Figure 1).

\section{Budget Management Research of Illinois}

\subsection{Budget Management Organizational Structure of Illinois}

Bureau of the Budget of Illinois State, the Performance Reviews Office, Infrastructure Committees are subordinate to the Executive Office of the State, and the heads of the Office of Budget Office and performance reviews are directly appointed by the governor; other-government sectors are the namely budget spending units.

Bureau of the Budget also have jurisdiction over the budget operation office, debt management office, income economic analysis office, project management office ,infrastructure office, environment and public protection office, education department of health and human resources service office, medical and child welfare department. The main responsibilities of the state Bureau of the Budget include:

- Make draft budget, assist the governor to submit the draft budget to parliament which including estimated revenue and expenditure of each item; 


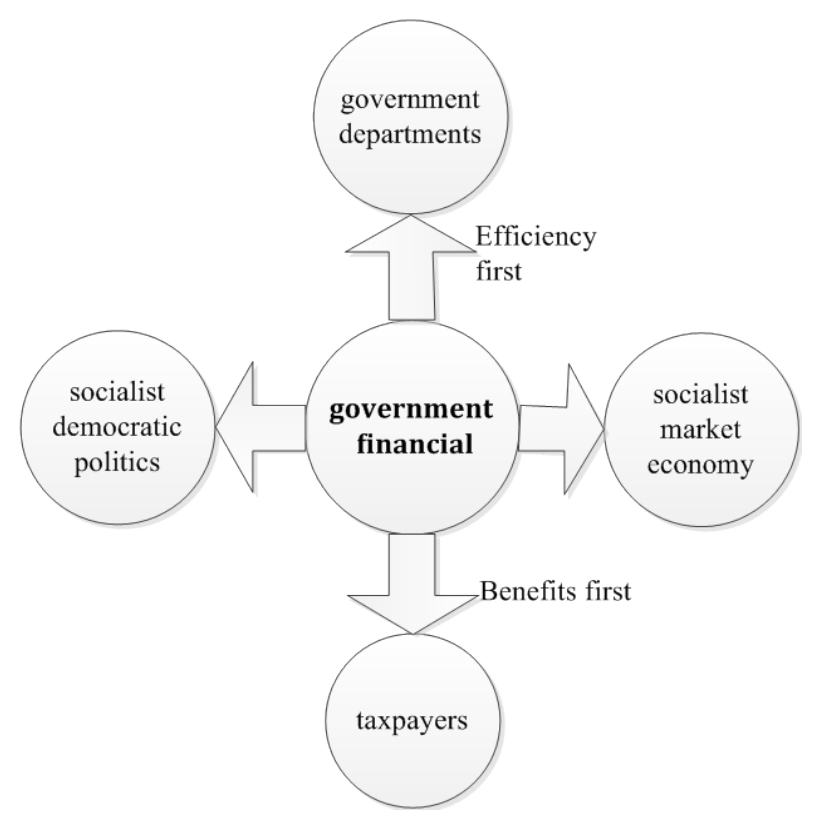

Figure 1. The Function positioning of Government financial.

- Project tracking management, assessment submitted by the budget sector, the goal of the project costs, the degree of importance of research, project coordination and implementation of various projects to make more efficient use of funds, reduce duplication of investment and unnecessary waste;

- The relationship between the finance department on the lower level coordination to ensure smooth communication;

- The expenditure control;

- Floatation and government bonds information disclosure (Chalk \& Hemming, 2010) (Figure 2).

\subsection{Key Responsibilities the State Performance Reviews Office}

- Responsible for the performance of newly increased non-infrastructure projects of the various departments of State, Budget Bureau arrange expenditures for non-infrastructure projects which are qualified.

- Each project of all departments which are within the scope of the jurisdiction of the governor is responsible submitted a comprehensive detailed review to determine whether the project is in the realization of each of the department's core mission is essential, or items can be reassigned to other departments, private companies or revocation; determine whether the project is necessary modifications to improve the quality of project services, efficiency and outreach, assessment.

- Developed evaluation criteria of the new projects jointly with the State Budget Office. Each department's new project which need the state government's government financial support, should have clear performance metrics which can determine whether the project was successful.

- The office has also established a Council of State Responsibility to assist in the performance review of state government departments (Hemming \& Kell, 2003).

\subsection{Basic Functions of Building Committee}

- Responsible for infrastructure projects or lease cost of the study;

- To study how to select and use different materials, energy systems (solar system), how to improve construction methods infrastructure projects in order to reduce construction costs and operating and maintenance costs;

- The buildings have been completed and construction-related technical standards to evaluate and make recommendations on a regular basis in order to ensure public safety, energy efficiency and economy (including the use of solar energy), reducing construction costs and operating and maintenance costs of infrastructure projects; 


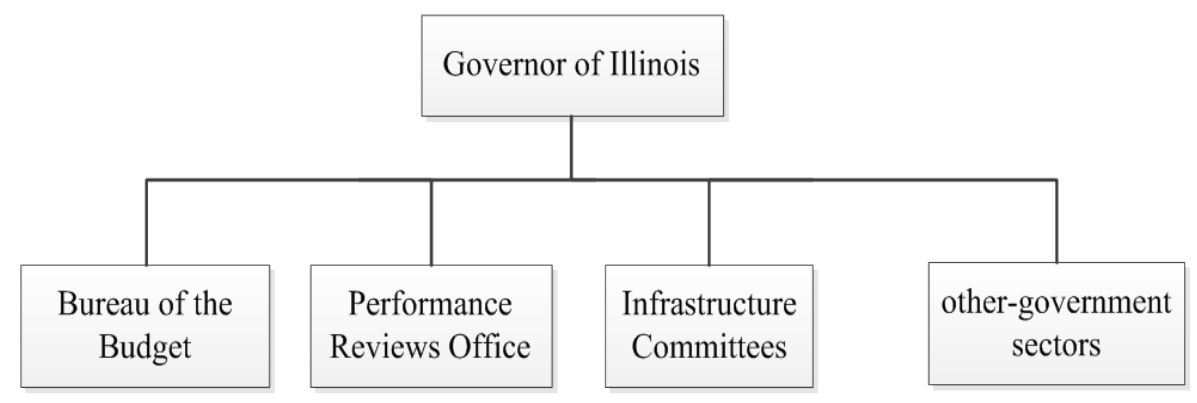

Figure 2. Budget management organizational structure of 1llinois.

- Help the state government departments to prepare a long-term capital expenditure every plan year.

Through the study of the budgeting process a state of the United States, it can be aware of the following differences in their budgeting and China's: the division of responsibilities between the government departments is more clear; there is a special department for budgeting, which make budget according to the governor's policy oriented; a long span of budgeting, the budget unit has plenty of time for the preparation of the department budget (Torres, 2004).

\section{Germany's Budget Management}

The advance of Germany's budget management embodied in excellent budget compiling system:

- To establish a very sound budget legal system provides for specific operational methods budgeting, implementation, monitoring and other aspects, such as "government financial constitution" the basic principles of the budget law, the federal budget ordinance, but Parliament will pass the annual budget approval develop the annual federal budget bill became;

- With a more scientific way of transfer payments;

- Has a complete forecast system of tax revenue. There are specialized institutions and organizations at all levels of professionals, experts and scholars from local tax departments to anticipate future fiscal revenue, and formed a regular meeting system;

- The entire budget process is more open and transparent. Such as the Federal Parliament to review the government budget, the entire contents of the annual budget bill, and the budget was relatively small, relevant background material, the results of the audit of the implementation of the budget is completely open to the community;

- Organizations, departments and public budgetary arrangements for the game formed institutionalized. In Germany the organizations through a variety of programs statements, arguments, debates, and even quarrel, make arrangements for the budget to get the basic realization of the idea (Corsetti \& Mackowiak, 2006).

\section{Budget Management Research of Tianjin, China}

According to finance scientific and meticulous management requirements, in recent years, Tianjin further deepen the reform of budget management sector by addressing the difficulties of reform, focusing on the establishment of a more advanced project budget management. Advanced Tianjin mode is mainly reflected in the following aspects.

- A good system that developed a "project expenditure budget management" and "government financial project expenditure budget management implementation details" and other regulations, there are explicit request to manage the expenditure budget of municipal budget units, comprehensively regulate and strengthen municipal projects expenditure budget management.

- Standardized budgeting, each department begin to develop spending plans of next year in the second quarter each year and project budget of the budget year must be within $120 \%$ of last year's budget, and report to Finance Bureau before September in the first year.

- The refinement budget content, $70 \%$ of funds must have a detailed list which including specific users and purposes; these projects which have not refined must be detailed before the end of September of the budget year according to the procedures prescribed. Otherwise, the budget will be subtracted and made new ar- 
rangements by the finance departments.

- Dynamic project management, use the project-library management that requires all the projects including the spending grassroots projects reported by expenditure budget units and authorities declared fully integrated into the sectoral project database management with uniform regulations, reasonable sort, scroll management.

- Strict implementation of the budget, it can't be changed after the budget is approved in principle, and changing procedures are strictly, and the annual adjustment budget of the total size shall not exceed $10 \%$; applying for a supplementary budget in process of execution is not available in principle. (except for emergency expenditures).

\section{The Function Positioning of Local Finance Department}

Combined with research of the advanced budget management mode, we believe that the functions of government financial regulators throughout the government financial management should be: that is the level of heads of government departments entrusted the management of government financial resources and assets related to co-ordinate the management of the organization, and provide professional information services and expertise services, specific functions are as follows:

1) Allocation of funds entrusted to examine whether the application of government financial resources consistent with the policy and government directives; Use discretion to achieve a balanced budget;

2) Entrusted with the custody of funds and assets:

a) Payment accounting;

b) The registration and summary of assets and liabilities;

c) Review the use of funds;

3) Control the rhythm of payments, realize the balance of payments; Cash flow balance;

4) The entrusted organization government financial performance management, performance result applied (carried out in accordance with the policy by means of performance management rewards and punishment);

5) Using the government financial data to statistics to analysis and prediction the status quo and trend of assets and liabilities, as well as stock, then support and advice for the decision of the government.

From the function and orientation of government financial management, government financial management is the trustee between the heads of government departments and unit; seen from the relationship of administrative and fiscal, government financial management servicing for administrative purposes, therefore, clarify the relationship between the administrative management and government financial management is the primary problem of government financial management reform.

Administrative performance is the goal that government pursue in the entire operation, the overall goal of our government is to build a highly developed socialist democracy and the socialist market economy, and therefore our government is a service-oriented government, its performance will be defined by the general public, ultimately they are government's clients (Li, 2011).

Government financial investment make the public get access to public services, the cost is a necessary investment that must to bear to keep government operations; the government's administrative performance is the output of government, such as the quality and effectiveness of public services. Government financial performance is actually contrasted between visible executive performance and government financial investment, fiscal performance is the ultimate measure of government performance standards. The ultimate goal of government financial management is based on a smaller cost in exchange for a higher level of administrative performance overall government departments.

Government financial is to provide the necessary government financial for administration, fiscal revenue and expenditure is reflected in the currency of administrative decision-making, therefore, government financial management is subordinate to administration, and fiscal reforms if we want to achieve real results that must be complemented by the administrative reform.

Also, because of the advisor and trustees is the functions and positioning of government financial management, the government financial management reform of the finance department must on the premise of administrative decision changes of heads of government departments and the administrative reform to budget units. For example, the medium-term fiscal planning is based on the medium-term planning of the policy agenda of certain heads of government departments. 
However, government financial is required to run the executive branch, and government financial is the adjusting methods to fulfill public responsibilities and interests of the government departments at all levels. therefore, the 18th CPC central committee proposed that "Finance is the basic and important pillar of national governance"; Jiwei Lou, the Secretary of Treasury of China ,think fiscal reform is the key to comprehensively deepen reforms, the Ministry of Finance to regulate the work of administrative services at all levels of government expenditure through the balance of the assessment, some scholars believe that the 18th CPC central committee's decisions based on government financial reform to forced administrative reforms. Visibly, fiscal reform is important and difficult in the government reform (Zhu, 2013) (Figure 3).

\section{Conclusion}

Budget management reform of the government financial management department should be divided into two phases. The first is to revise unreasonable approval processes and make standardizations for budget management. The second stage is to deepen management and reform achievements and focus on solving the emphasis and difficulty of the reform.

The key of the government financial system reform is to reform the budget management system, the government budget management reform must be based on the actual situation; the foreign advanced mode is a reference, and we also should have analysis of advanced mode in China; only in this way can we make budget management more efficient and accurate. Right direction and the scientific method are crucial for the effectiveness of the reform; government financial management department should constantly sum up in practice, continue learning, and then reach the goals of establishing a modern government financial system early. The innovation of this paper is to get budget management as the breakthrough point, and carry on the case analysis of foreign mode; this article provides a good advice to the modern financial reform which is about to begin (Figure 4).

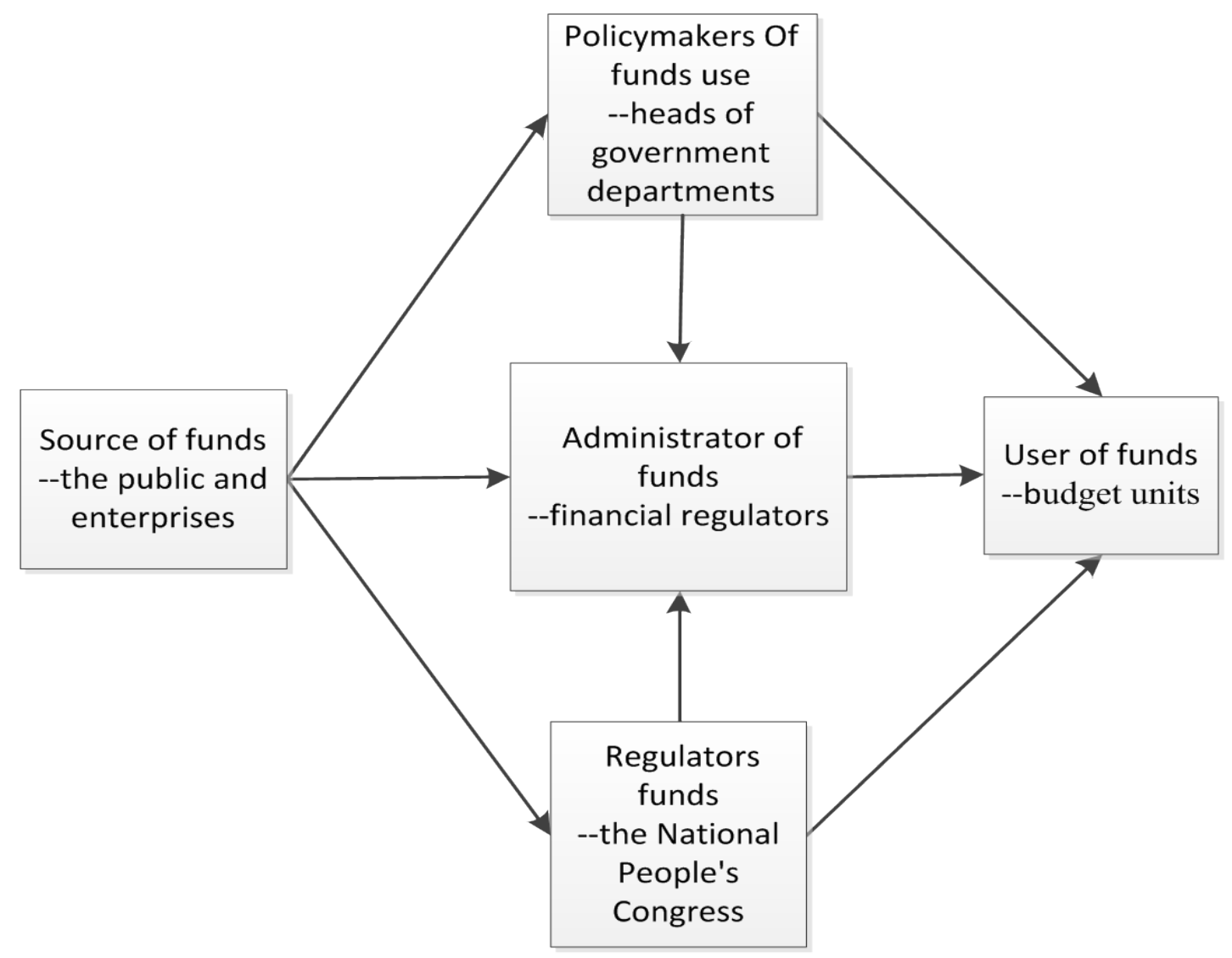

Figure 3. The functions of government financial regulators. Notes: The arrows represent that the first object have influence to the second one. 


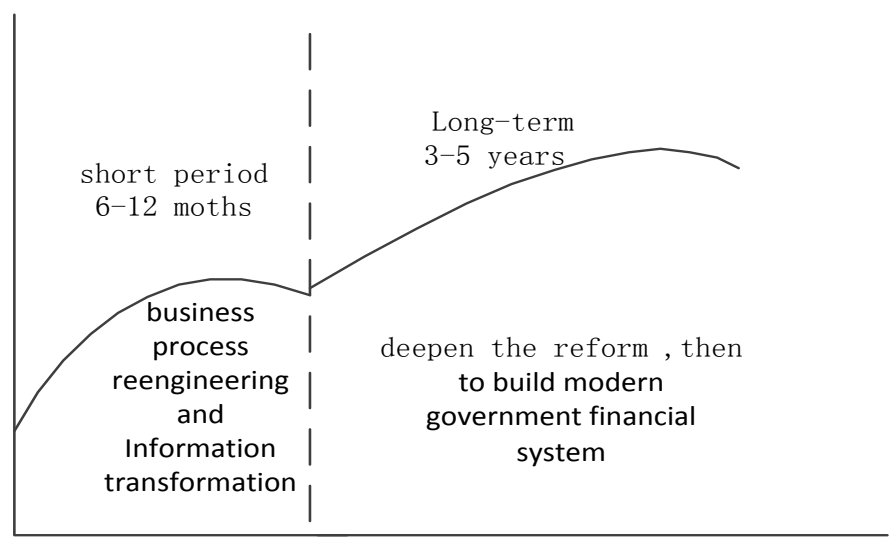

Stage 1

Stage 2

Figure 4. Two phases of reform.

\section{Acknowledgements}

Thanks for Professor Hongsheng Xia and other professors of management school of Jinan University for giving advice in my study and research during the past 3 years. Also, I want to thank my families, it's they that support me quietly. I would not be where I am today without them. Sincerely thank all the people who helped me again.

\section{References}

Chalk, N., \& Hemming, R. (2010). Assessing Fiscal Sustainability in Theory and Practice. IMF Working Paper, 1, 1-81. http://dx.doi.org/10.5089/9781451859195.001

Corsetti, G., \& Mackowiak, B. (2006). Fiscal Imbalances and the Dynamics of Currency Crises. European Economic Review, $1,91-115$.

Hemming, R., \& Kell, M. (2003). Enhancing Fiscal Responsibility: Transparency, Rule, and IFA. Seminar on Finance Planning and Policy, 1, 226-243.

Lee, R. D., \& Johnson, R. W. (2010). Public Budget System (7th ed.). Shanghai: Finance and Economics of Shanghai University Press.

Li, G. F. (2011). Our Budget Reform Restriction Factor Analysis. Journal of Hubei Economy Academy (Humanities and Social Science Edition), 1, 127-150.

Strengthen the Budget Management and Supervision System Research Group (2010). China's Finance.

http://czzz.mof.gov.cn/

The Financial Secretary (2003). Budget Management Experience in International Perspective. Beijing: China Financial Economic. http://www.mof.gov.cn/index.htm

Torres, L. (2004). Accounting and Accountability: Recent Developments in Government Financial Information Systems. Public Administration and Community Development, 1, 447-456. http://dx.doi.org/10.1002/pad.332

Zhu, Z. F. (2013). Budget Management Transformation Path Research. Economic Review, 2, 42-49. 
Scientific Research Publishing (SCIRP) is one of the largest Open Access journal publishers. It is currently publishing more than 200 open access, online, peer-reviewed journals covering a wide range of academic disciplines. SCIRP serves the worldwide academic communities and contributes to the progress and application of science with its publication.

Other selected journals from SCIRP are listed as below. Submit your manuscript to us via either submit@scirp.org or Online Submission Portal.
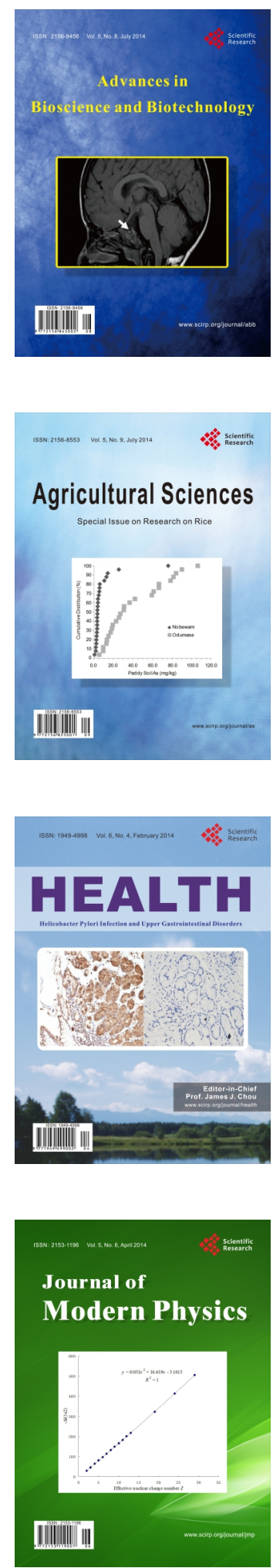
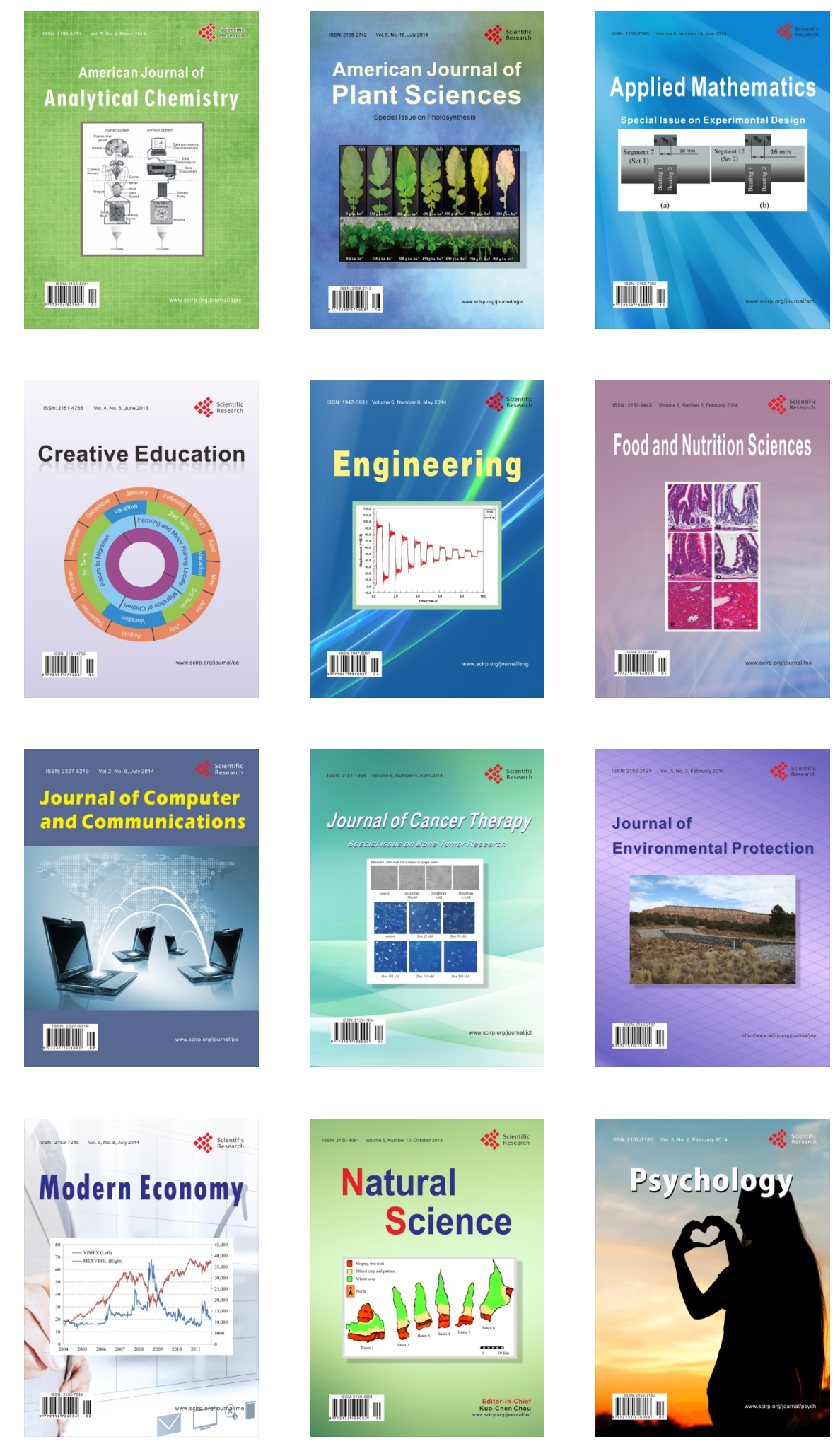